\title{
OS EXPERIMENTOS DE GRIFFITH NO ENSINO DE BIOLOGIA: A TRANSPOSIC̣ÃO DIDÁTICA DO CONCEITO DE TRANSFORMAC̣ÃO NOS LIVROS DIDÁTICOS
}

\author{
Caroline Belotto Batisteti* \\ Elaine Sandra Nicolini Nabuco de Araujo** \\ João José Caluzi ${ }^{* *}$
}

RESUMO: Os experimentos de Griffith sobre a transformação de bactérias Pneumococcus, são tidos como importantes no processo de reconhecimento da relação DNA/hereditariedade. O presente estudo teve por objetivo analisar a transposição didática do conceito de transformação bacteriana, desde as descrições de Griffith até sua abordagem nos livros didáticos de Biologia. Percebemos que o contexto histórico e a relação entre a transformação bacteriana e o reconhecimento do DNA como material genético são pouco explorados. Considerando a riqueza de conhecimentos, de diferentes áreas, que os experimentos de Griffith abrangem, sugerimos uma transposição didática do conceito de transformação bacteriana que envolva uma integração de conteúdos, tendo como ponto central a abordagem histórica desses experimentos.

Palavras-chave: Transformação Bacteriana. Transposição Didática. Ensino de Biologia.

\section{GRIFFITH'S EXPERIMENTS ON BIOLOGY TEACHING: THE DIDACTIC TRANSPOSITION OF THE CONCEPT OF TRANSFORMATION IN DIDACTIC BOOKS}

* Mestre pelo Programa de Pós-Graduação em Educação para a Ciência da Faculdade de Ciências da Universidade Estadual Paulista (UNESP).

E-mail:

carolbatisteti@yahoo.com.br

* * Pesquisadora do Centro de Divulgação e Memória da Ciência e Tecnologia (CDMCT) da Universidade Estadual Paulista (UNESP). E-mail: centro@fc.unesp.br *** Professor do Departamento de Física e do Programa de Pós-Graduação em Educação para a Ciência da Faculdade de Ciências da Universidade Estadua Paulista (UNESP) E-mail: caluzi@fc.unesp.br

ABSTRACT: Griffith's experiments regarding bacterial transformation Pneumococcus are regarded as essential when related to DNA/heredity recognition process. The aim of the current study is to assess the didactic transposition of the concept of bacterial transformation since the Griffith's descriptions until its current approach on didactic books. We realized that the historical context and the relationship between bacterial transformation and DNA recognition as genetic material are poorly explored. The core of our paper is the historical approach of those experiments. By considering the wide richness of the knowledge that is ranged on Griffith's experiments, we suggest a didactic transposition concerning bacterial transformation in the learning process, involving an integration of contents.

Keywords: Bacteria Transformation. Didactic Transposition. Biology Teaching. 


\section{INTRODUCุÃO'}

O grande número de pessoas acometidas por pneumonia após a $1^{\mathrm{a}}$ Guerra Mundial (1914-1918) desencadeou uma preocupação e busca pela produção de uma vacina para essa doença. Um dos profissionais empenhados em auxiliar na resolução dessa questão era Frederick Griffith (1881-1941)2, médico militar britânico, especialista em microbiologia. Em meio aos estudos e experimentos que realizou com as bactérias pneumococos, causadoras da pneumonia, Griffith observou e descreveu um fenômeno que denominou de transformação. Inicialmente ele estava interessado em explicar a presença de dois ou mais tipos de pneumococos em uma amostra de secreção coletada de um paciente. Griffith realizou vários experimentos envolvendo a transformação de um tipo de pneumococos para o outro, a partir da inoculação de culturas em ratos. Alguns desses experimentos foram reproduzidos in vitro por outros autores, incluindo Dawson e Sia (1931) e Avery e colaboradores (1944). Estes últimos estavam empenhados em identificar a natureza química do material responsável pela transformação bacteriana, que, de acordo com seus resultados seria o DNA.

Atualmente, é consenso que a molécula de DNA é responsável pela hereditariedade. No entanto, esse conhecimento é resultado de uma série de pesquisas anteriores, entre elas as de Griffith. Sob uma perspectiva contemporânea, a abordagem dos estudos desse médico, em especial aqueles referentes ao processo de transformação bacteriana, descritos em seu artigo de $1928^{3}$, mostra-se como um estratégia interessante no ensino de Biologia, pois abrange conteúdos de diversas áreas, tais como, Microbiologia, Biologia Molecular, Bioquímica e Biotecnologia.

Sabemos que o conceito de transformação está presente nos livros didáticos de Biologia voltados para o Ensino Médio. O objetivo do presente estudo é verificar a transposição didática, ou seja, as transformações que esse conceito sofreu desde as descrições de Griffith até sua abordagem nos livros didáticos utilizados presentemente. A partir dessa análise, sugerimos uma estratégia didática, que tem os experimentos de Griffith como eixo central, a fim de promover uma integração de conteúdos de Genética e Microbiologia para o Ensino Médio.

\section{OS EXPERIMENTOS DE GRIFFITH}

Frederick Griffith dedicou-se ao estudo sobre os tipos de pneumococos em casos de pneumonia lobar de abril de 1920 a março de 1927, quando percebeu a presença de dois ou mais tipos de pneumococos em uma amostra de secreção coletada de um paciente. Na tentativa de explicar esta observação, realizou vários experimentos envolvendo a transformação de um tipo de pneumococos para outro, a partir da inoculação ${ }^{4}$ de culturas em ratos. A 
Tabela 1 apresenta o total de casos de pneumonia examinados e a incidência em porcentagem dos tipos de pneumococos encontrados.

Tabela 1: Tipos de pneumococos em pneumonia lobar (GRIFFITH, 1966, p.130).

\begin{tabular}{c|c|c|c|c|c} 
& Total de casos & \multicolumn{4}{|c}{ Porcentagem de incidência dos Tipos } \\
\cline { 3 - 5 } Período de investigação & examinados & Tipo I & Tipo II & Tipo III & Grupo IV \\
\hline Abril 1920 - Jan. 1922 & 150 & 30.6 & 32.6 & 6.6 & 30.0 \\
Fev. 1922 - Out. 1924 & 61 & 42.6 & 21.3 & 3.2 & 32.7 \\
Nov. 1924 - Mar. 1927 & 67 & 34.3 & 7.4 & 4.4 & 53.7
\end{tabular}

O principal ponto de interesse da investigação realizada por Griffith foi "a diminuição progressiva no número de casos de pneumonia devida ao pneumococo Tipo II [....] os números podem revelar um real decréscimo local do Tipo II, e um correspondente aumento dos casos do Grupo IV" (GRIFFITH, 1966, p. 130). A despeito da verificação, em uma amostra (secreção) de uma linhagem do grupo IV isolada, coletada em estágio avançado da pneumonia, Griffith (1966) ressaltou que isto não significava que este grupo de pneumococos tenha sido o causador da doença, visto que, ao examinar várias amostras de secreções coletadas em diferentes períodos e advindas de um mesmo caso, outros tipos foram identificados concomitantemente.

Um exemplo, citado por Griffith, foi a produção de culturas do Tipo I e de três linhagens do Grupo IV, a partir de um material (secreção) coletado no $6^{\circ}$ dia da doença (quando a crise ainda não tinha ocorrido). Segundo Griffith (1966), três explicações são possíveis para a presença de dois ou mais tipos sorológicos em um mesmo caso, sendo elas:

1. O paciente que era previamente portador de várias linhagens do grupo IV tornouse infectado com uma linhagem do Tipo I que produziu a pneumonia. Não há evidências para mostrar qual dos tipos estava presente no pulmão pneumocócico, mas eu penso que o Tipo I pode ter sido o causador da doença.

2. O paciente quando normal era portador em sua nasofaringe de uma linhagem do Grupo IV. Devido a uma condição favorável para a mutação, um tipo de pneumococos, neste caso Tipo I, foi evoluindo em suas vias aéreas, sendo capaz de causar a pneumonia. Nessa hipótese, os tipos sorológicos diferentes seriam evidências de progressiva evolução.

3. Por outro lado, as linhagens do Grupo IV poderiam ser derivadas do Tipo I no decurso de resistência bem sucedida contra essa última linhagem. Com o aumento de substâncias imunes ou tecidos resistentes, o Tipo I poderia ser finalmente eliminado, e permaneceria lá apenas o Grupo IV com cepas quase certamente de menor infecciosidade e, talvez de menor complexidade de estrutura antigênica (GRIFFITH, 1966, p. 130-131).

A presença de uma mistura dos vários tipos sorológicos em uma mesma amostra de um caso de pneumonia fatal ocasionada pelo Tipo I e a ausência de outros tipos sorológicos, além desse, no pulmão do mesmo paciente, poderia sugerir, segundo Griffith (1966) que, 
[...] as estirpes secundárias, isto é, Grupo IV e Tipo III estavam presentes nas vias aéreas superiores antes da infecção com as estirpes mais invasoras do Tipo I e II. No balanço das probabilidades, a permutabilidade dos tipos não parece ser uma hipótese menos provável do que a de infecção com quatro ou cinco diferentes e inalteráveis variedades sorológicas de pneumococos. Além disso, a incapacidade para encontrar mais de um tipo no pulmão de um caso fatal de pneumonia não seria prova conclusiva contra a hipótese da modificação, uma vez que a rescisão fatal, por si só, indica uma ausência de anticorpos protetores que podem ser necessários para iniciar uma alteração no tipo de pneumococo infectante. Nesse caso, uma punção pulmonar poderia fornecer indicações mais precisas (GRIFFITH, 1966, p.133).

Griffith, então, descreveu uma série de experimentos laboratoriais favoráveis à hipótese da transformação, demonstrando alterações nos tipos sorológicos. Ele utilizou formas variantes de pneumococos avirulentas e virulentas. Martin H. Dawson, no seu artigo de 1928, resumiu as características que distinguem as duas formas de pneumococos:

As formas S são virulentas; elas produzem uma substância solúvel específica, que depende da especificidade do tipo; e elas formam colônias que têm uma superfície lisa quando examinada por luz refletida. As formas R são avirulentas; elas não produzem a substância solúvel específica e elas formam colônias que têm uma superfície rugosa quando similarmente examinadas (DAWSON, 1928, p.577).

A aparência lisa das colônias está relacionada à presença de uma cápsula de polissacarídeos nas bactérias virulentas. As bactérias não virulentas não apresentam esse envoltório. De acordo com Dawson (1928), o bacteriologista britânico J. A. Arkwright, em 1921, foi o primeiro a empregar os termos $\mathrm{S}$ (smooth) e R (rough) para designar as duas variantes da mesma espécie de bactérias, e Griffith, o primeiro a identificar duas variantes correspondentes em pneumococos.

Em seus experimentos sobre modificação, Griffith utilizou linhagens de pneumococos atenuadas $\mathrm{R}$, obtidas de culturas de linhagens virulentas S. Ele verificou a reversão para formas virulentas $S$ a partir da inoculação sob a pele de ratos, de uma larga dose de cultura avirulenta $\mathrm{R}$ atenuada. Para ele, a reversão da virulência ${ }^{5}$ era facilitada pela massa de cultura inoculada subcutaneamente no rato, a qual forma um nidus ${ }^{6}$ em que os pneumococos $\mathrm{R}$ são capazes de se desenvolver em formas encapsuladas e invadirem a corrente sanguínea. Entretanto, segundo Griffith (1966) "esta proteção vinda de um mecanismo normal de defesa do animal não pode ser o único fator responsável por produzir a mudança, desde que, pneumococos atenuados $\mathrm{R}$ podem sobreviver inalterados em tecidos subcutâneos por duas ou três semanas sem qualquer proteção” (p.145).

$A$ reversão da variante $R$ para $S$ era devida, conforme Griffith, ao fato da linhagem $R$ atenuada (obtida originalmente de linhagem $S$ ) poder reter em sua estrutura um antígeno $\mathrm{S}$ original, insuficiente em circunstâncias ordinárias de exercer um efeito patogênico ${ }^{7}$ no animal. Quando a linhagem é inoculada em considerável massa sob a pele do rato, "a maioria dos penumococos se rompe e 
o antígeno $\mathrm{S}$ liberado pode fornecer um pabulum que os pneumococos $\mathrm{R}$ viáveis podem utilizar para a construção de sua estrutura rudimentar S" (GRIFFITH, 1966, p. 145-146).

A substância ou antígeno S é conforme Griffith,

[...] uma estrutura proteica específica dos pneumococos virulentos que os capacita a produzir um carboidrato solúvel específico. Esta proteína parece ser necessária como material que capacita a forma $\mathrm{R}$ a construir a estrutura proteica específica da forma $\mathrm{S}$ (GRIFFITH, 1966, p.67).

Griffith realizou experimentos para verificar se condições mais favoráveis à reversão poderiam ser fornecidas a partir da inoculação em ratos de uma massa de cultura derivada de pneumococos virulentos mortos juntamente com uma pequena quantidade de pneumococos $\mathrm{R}$ atenuados. Isso evidenciaria, segundo ele, que o nidus e a alta concentração de antígeno $\mathrm{S}$ servem como um estímulo ou alimento para a reversão. Uma breve descrição de um dos experimentos de Griffith é apresentada a seguir.

Uma cultura de pneumococos virulentos S do Tipo II foi morta por aquecimento à $100^{\circ 8} \mathrm{C}$. A cultura foi concentrada por centrifugação e inoculada subcutaneamente em 4 ratos (50 c.c. em cada) juntamente com 0.5 c.c. da cultura $\mathrm{R}$ do Tipo II. Os 4 ratos morreram após 3 a 5 dias com numerosos pneumococos encapsulados em seu sangue, culturas as quais davam uma típica reação de aglutinação' ${ }^{9}$ da linhagem virulenta Tipo II.

Com relação aos experimentos de reversão utilizando tipos distintos, Griffith concluiu que a inoculação em tecidos subcutâneos de ratos de uma linhagem $\mathrm{R}$ derivada de um tipo, juntamente com uma grande dose de cultura virulenta de outro tipo, morta por aquecimento à $60^{\circ} \mathrm{C}$, resulta na formação de pneumococos $\mathrm{S}$ virulentos do mesmo tipo da cultura aquecida. Por exemplo, a partir da inoculação em ratos de culturas S do Tipo III aquecidas à $60^{\circ} \mathrm{C}$ e de linhagens $\mathrm{R}$ atenuadas do Tipo I ou II, obtinham-se colônias de linhagens S do Tipo III dos ratos mortos devido à pneumonia. As colônias S do Tipo III foram encontradas em uma frequência maior em ratos inoculados com linhagens $\mathrm{R}$ do Tipo II do que naqueles inoculados com linhagens R do Tipo I. Segundo Griffith,

Esse fato fornece algum suporte à ideia que o tipo particular de linhagem R é o fator importante na produção de colônias do Tipo III. Acidentalmente, isto é evidência adicional contra a hipótese que pneumococos viáveis Tipo III persistiram na cultura após aquecimento (GRIFFITH, 1966, p.158).

A justificativa de que a mudança teria ocorrido devido à sobrevivência de alguns pneumococos, após o aquecimento, foi desconsiderada, pois segundo Griffith, por meio dos métodos de cultura e inoculação animal, não houve evidências de pneumococos viáveis nas culturas aquecidas. Para ele, "parece não haver outra alternativa para a hipótese da transformação dos tipos" (GRIFFITH, 1966, p.170). 
As Figuras 1, 2 e 3, apresentadas a seguir, ilustram o experimento de Griffith referente à transformação utilizando Tipos distintos, isto é, pneumo$\operatorname{cocos} \mathrm{R}$ atenuados do tipo II e pneumococos virulentos (S) do tipo III.
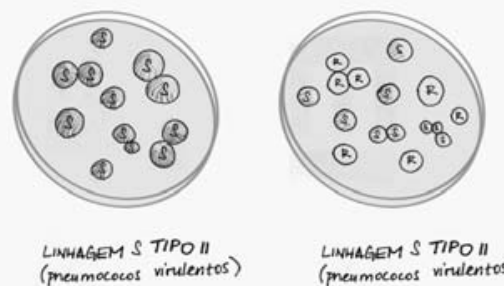

LINHAGEM S TIPO II (preamococos virulentos)

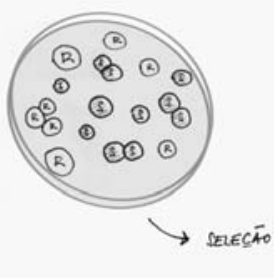

(๔) (尺)

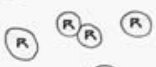

(a)

LWHAGEM R - ATENUADA(7neumococos nio viralentos)

Figura 1 - Esquema sobre 0 modo como Griffith obteve linhagem $R$ atenuada a partir de linhagem S Tipo II.

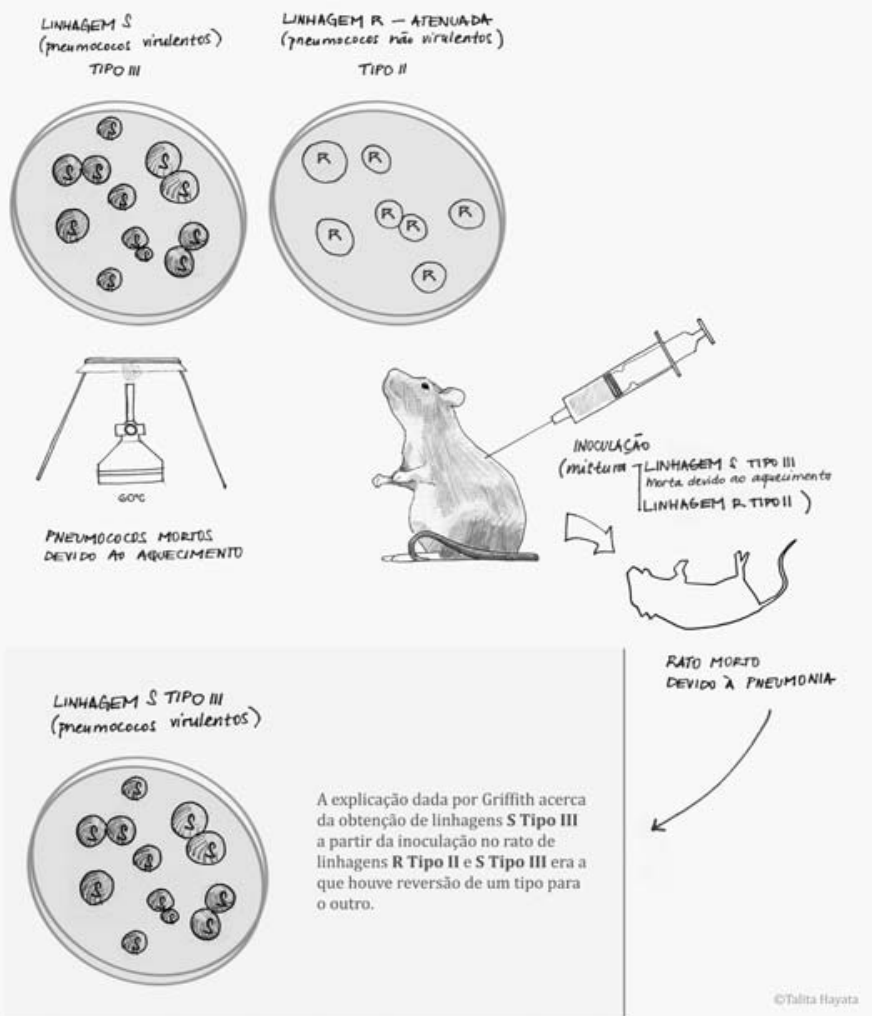

Figura 2 - Esquema sobre o experimento de Griffith acerca da transformação de um Tipo de pneumococo em outro. A figura mostra a inoculação simultânea no rato de grande quantidade de pneumococos de linhagem $S$ Tipo III mortos por aquecimento e pequena quantidade de linhagem $R$ atenuada Tipo II. Isso ocasionou a morte do rato e uma análise do material coletado deste apresentou pneumococos da linhagem S Tipo III. 


\section{Qual a explicação de Griffith para a reversão dos tipos?}

A substância $\mathrm{S}$ quando liberada pelo rompimento das bactérias $\mathrm{S}$ mortas pelo calor, constitui-se num alimento para que as bactérias $\mathrm{R}$ construam estruturas S (transformem-se em S).
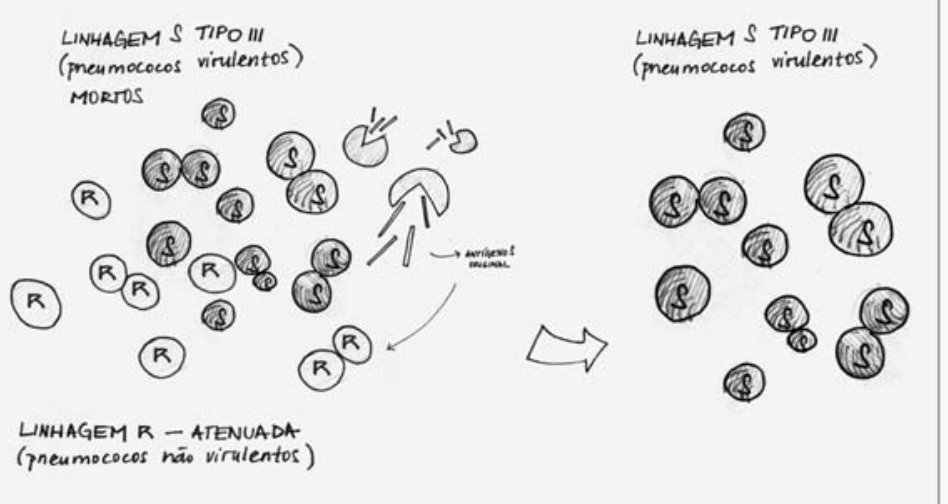

Figura 3 - Representação da explicação de Griffith para a hipótese de transformação dos tipos. Para ele, os pneumococos da linhagem S Tipo III quando aquecidos, se rompiam e liberavam um "antígeno S original" responsável pela virulência. Este antígeno, em contato com os pneumococos $\mathrm{R}$ Tipo II viáveis, constituía-se em um "alimento" para que eles construíssem a estrutura $\mathrm{S}$. Como resultado obtinha-se a reversão de pneumococos $\mathrm{R}$ avirulentos Tipo II em pneumococos $\mathrm{S}$ virulentos Tipo III.

A palavra transformação foi utilizada por Griffith para referir-se à reversão de uma variante para outra e, para ele, a substância $S$ necessária para ocorrência deste processo era uma proteína. A indução à reversão foi também testada in vitro, mas Griffith não obteve sucesso.

Em trabalhos posteriores, a substância responsável pela transformação foi isolada e identificada como sendo o DNA (AVERY et al., 1944). Detalhes acerca da proposta do DNA como material genético estão sendo investigados em um estudo mais aprofundado por nós realizado.

\section{A TRANSPOSIC̣ÃO DIDÁTICA}

O conceito de transposição didática foi desenvolvido por Michel Verret, em 1975 e amplamente divulgado a partir do trabalho de Yves Chevallard e Marie-Albert Joshua intitulado Um exemplo de análise da transposição didática: a noção de distância, publicado em 1982.

Aqui discutiremos alguns aspectos da transposição didática do conceito de transformação com base em Chevallard (1991) e Astolfi e Develay (2001). Segundo Chevallard (1991): 
Um conteúdo de saber que tem sido designado como saber a ensinar, sofre a partir de então, um conjunto de transformações adaptativas que vão torná-lo apto para ocupar um lugar entre os objetos de ensino. $\mathrm{O}$ "trabalho" que transforma de um objeto de saber a ensinar em objeto de ensino é denominado de transposição didática (p.45).

Para Chevallard, o saber sábio (científico), uma vez designado como um saber a ensinar (explicitamente presente nos programas de Ensino) sofre uma série de transformações até tornar-se um saber ensinado. Para se tornar apto a ser ensinado, o saber sábio, deverá sofrer certas deformações. Assim, o saber ensinado, é necessariamente distinto do saber a ensinar. De maneira simplificada, temos:

\section{Saber sábio $\longrightarrow$ saber a ensinar $\longrightarrow$ saber ensinado}

Ao longo do processo de transposição, as modificações ocorridas no saber sábio são influenciadas pelo que Chevallard denominou de noosfera, sendo esta, uma área em que se estabelecem debates entre os representantes do sistema de Ensino e os representantes da sociedade. O saber ensinado se torna obsoleto, contrariando os interesses da sociedade, assim, emergem conflitos, negociações e soluções que conclamam adequações para encurtar a distância entre esse e o saber científico contemporâneo.

Quando os conceitos científicos se tornam objetos de ensino pode ocorrer, segundo Chevallard (1991), a despersonificação, descontemporialização, descontextualização e naturalização. Ele explicou que a despersonificação está relacionada à publicidade do saber, que promove certo grau de despersonalização à medida que este é compartilhado pela comunidade científica. Em relação à descontemporialização, ele mencionou que, o saber ensinado torna-se desvinculado de algum tempo ou lugar, sendo exilado de suas origens e separado de sua construção histórica no contexto do saber sábio. Tendo em vista que os saberes sábios possuem elementos variáveis e invariáveis, uma vez que são estabelecidas correspondências entre esses e os saberes ensinados, muitos elementos invariáveis são descontextualizados. Há uma recontextualização, porém, com muita frequência o saber ensinado se encontra profundamente modificado. No que se refere à naturalização, esta confere ao saber ensinado a evidência incontestável das coisas naturais, e é sobre esta natureza que a escola funda valores e administra a ordem didática. Os autores Astolfi e Develay (2001) ao discutirem a transposição didática nas ciências no geral, e nas ciências biológicas, em particular, enfatizaram que, quando um elemento do saber sábio é designado como objeto de ensino, sua natureza é fortemente modificada, já que "encontram-se deslocadas as questões que ele permite resolver, bem como a rede relacional que mantém com os outros conceitos. Existe assim, uma "epistemologia escolar" que pode ser distinguida da epistemologia em vigor nos saberes de referência.” (ASTOLFI; DEVELAY, 2001, p. 48). 
Três pontos de vista devem ser considerados, segundo Astolfi e Develay (2001, p. 50-51), para dar conta das mudanças de estatuto epistemológico do saber sábio:

a) O "efeito de reformulação" que ocorre na apresentação dos resultados das pesquisas à comunidade científica. Há um distanciamento entre a lógica da exposição dos resultados e o contexto de desenvolvimento da pesquisa.

b) O processo de dogmatização, ou seja, a relação com posições epistemológicas dominantes, relacionadas ao poder da observação e do empirismo como "filosofia espontânea dos sábios". Nesse sentido é conveniente que haja uma vigilância particular para se evitar reescritos abusivos e para se inquirir consultas frequentes às publicações originais.

c) A inevitabilidade da transposição didática. "Pois a escola nunca ensinou saberes ('em estado puro', é o que se desejaria dizer), mas sim conteúdos de ensino que resultam de cruzamentos complexos entre uma lógica conceitual, um projeto de formação e exigências didáticas.” (ASTOLFI; DEVELAY, 2001, p.51).

Em relação ao item b, destacamos que Chevallard também chamou a atenção para a necessidade da vigilância epistemológica no processo de transposição didática. Para ele, ao longo deste processo, há um inevitável distanciamento entre os saberes ensinados e os saberes sábios, e nesse sentido, é preciso estar atento às distorções que podem ser ocasionadas por esse afastamento. $\mathrm{Na}$ teoria de Chevallard, o saber ensinado é legitimado pelo saber sábio, sendo importante que o professor, em meio às transformações que o conteúdo sofre ao ser ensinado em sala de aula, tenha como referência o saber sábio, exercendo assim uma constante vigilância epistemológica.

Leal (2001) realizou um estudo piloto sobre os processos de transposição didática da cadeia alimentar presentes nos programas escolares e nos livros didáticos, com o intuito de entender em que medida o saber do sábio, ao ser concebido como um saber a ensinar e como objeto de ensino, é ou não, preservado. Em sua análise, Leal observou que o processo de transposição didática demanda criatividade, mas exige também o que Chevalard e Verret denominaram de vigilância epistemológica. Esta é importante para que não ocorra a descaracterização do saber sábio, de tal maneira que haja uma modificação profunda de um determinado conteúdo original quando este é abordado em sala de aula. Sobre a transposição de conteúdos acerca de cadeia alimentar, Leal mencionou que:

[...] podemos dizer, com base no exame do material selecionado, que houve cuidado no sentido de não se transfigurar o conteúdo. O que se mantém problemático, no entanto, é o fato do conteúdo estudado, ao ser "universalizado" e "objetivado", perder a memória de sua gênese, de sua autoria, de sua história. Quando resgatamos a história do conceito, identificamos o contexto que o gerou e as implicações de sua criação, temos a oportunidade de retomar a interpretação (narrativa) e, desse modo, dar significados mais plurais e ricos às metáforas, às analogias, aos modelos que vão sendo construídos/ reconstruídos no percurso da transposição didática (LEAL, 2001, p.70). 
Depreende-se da citação anterior, a importância da utilização de abordagens históricas no ensino, uma vez que a partir delas, as problemáticas da transposição didática destacadas por Chevalard, como despersonificação, descontemporialização, descontextualização e naturalização, são minimizadas.

A seguir, apresentaremos nossa análise, que levou em consideração os aspectos de despersonificação, descontemporialização, descontextualização e naturalização, sobre a transposição didática do conceito de transformação de bactérias, desde a ideia contida nos trabalhos de Griffith até os livros didáticos de Biologia atuais.

\subsection{A transposição didática do conceito de transformação}

Consultamos quatro livros didáticos de Biologia recomendados pelo Programa Nacional do Livro Didático para o Ensino Médio (BRASIL, 2009) para analisarmos as possíveis mudanças decorrentes da transposição didática acerca do conceito de transformação bacteriana. Optamos por não mencionar os autores e títulos dos livros investigados. Os denominamos de A, B, C e D.

Para nortearmos a análise, estabelecemos as seguintes categorias e subcategorias: didáticos.

1) Presença do conceito de transformação bacteriana nos livros

2) Localização: Parte ou capítulo do livro em que o conceito é abordado.

3) Formas de abordagem do conceito.

3.1) Histórica: Faz referência ao contexto histórico em que se deu o desenvolvimento do conceito.

3.2) Atual: Apresenta explicações sobre o conceito baseadas em conhecimentos aceitos atualmente.

Dos livros analisados, dois deles (livros A e C) não mencionaram os experimentos de Griffith, apenas explicações atuais sobre o processo de transformação bacteriana. O livro D não apresentou explicações sobre esse conceito. No livro B encontramos uma abordagem histórica e uma atual sobre transformação de bactérias.

Quanto à localização, verificamos que, nos três livros em que o conceito de transformação é abordado, esse aparece inserido no conteúdo referente ao Reino Monera, em que são estudadas as características das bactérias, incluindo suas formas de reprodução. A Tabela 2 sumariza os resultados encontrados. 
Tabela 2: Categorização dos dados encontrados a partir da análise dos livros didáticos de Biologia.

\begin{tabular}{c|c|c|c|c}
\multirow{2}{*}{ Categorias } & \multicolumn{4}{|c}{ Livros Didáticos Analisados } \\
\cline { 2 - 5 } & A & B & C & D \\
\hline Presença do conceito & Sim & Sim & Sim & \\
& Reino Monera - & Reino Monera - & Reino Monera - & - \\
& Reprodução & Reprodução & Reprodução & \\
Abordagem histórica & bacteriana & bacteriana & bacteriana & - \\
Abordagem atual & Não & Sim & Não & -
\end{tabular}

Em relação à transposição didática do conceito de transformação, investigamos a presença de elementos que caracterizam os processos de despersonificação, descontemporialização, descontextualização e naturalização. Esses podem ser observados nas Figuras 4 e 5, em que são apresentados alguns trechos dos livros A e C, respectivamente.

transformação: uma bactéria absorve moléculas de DNA disponíveis no meio e incorpora-as ao seu DNA Essas bactérias ficam então com constituição genética modificada e são chamadas de transformadas;

Figura 4 - Trecho retirado do Livro A, referente à explicação atual sobre transformação bacteriana.

As bactérias também apresentam formas sexuadas de reprodução, em que ocorre passagem de material genético da bactéria doadora para a receptora. $\mathrm{Na}$ transformação, uma célula bacteriana incorpora DNA presente no ambiente. Na transdução, vírus funcionam como vetores, transferindo DNA de uma célula bacteriana para outra. A conjugação envolve a passagem, através de uma ponte intercelular temporária, de DNA de uma bactéria doadora para uma receptora.

Figura 5 - Trecho retirado do Livro C, referente à explicação sobre os tipos de reprodução de bactérias.

Nos trechos expostos anteriormente não foram mencionados os indivíduos que contribuíram para a construção do conceito de transformação bacteriana e tão pouco as questões problematizadoras que motivaram seu desenvolvimento. Priorizou-se a explicação atual do processo que é apresentada como definitiva, o que não instiga novos questionamentos.

A Figura 6, exposta a seguir, apresenta um trecho retirado do livro B. Diferentemente dos livros A e C, esse apresenta algumas informações históricas que procuram personificar, contextualizar e contemporizar o conceito aqui discutido. Em relação à afirmação "Griffith concluiu que devia haver um "princípio transformante", então de natureza desconhecida", constatamos equívocos históricos. Griffith, em seu artigo de 1928, não mencionou o termo princípio transformante. Não sabemos quem cunhou a expressão "princípio ou fator transformante”, que é bastante utilizada nos livros didáticos atuais e atribuída a 
Griffith. Conforme já mencionado, em seu trabalho ele usou a expressão transformação para designar a reversão de um tipo de pneumococo em outro. Além disso, é preciso relativizar a ideia de "natureza desconbecida" do princípio transformante. A substância responsável pela transformação, no período em que Griffith realizou seus experimentos, não era identificada como o DNA, mas, conforme já explicitado no item Os experimentos de Griffith, esse pesquisador considerava que o antígeno $\mathrm{S}$ era de natureza proteica.

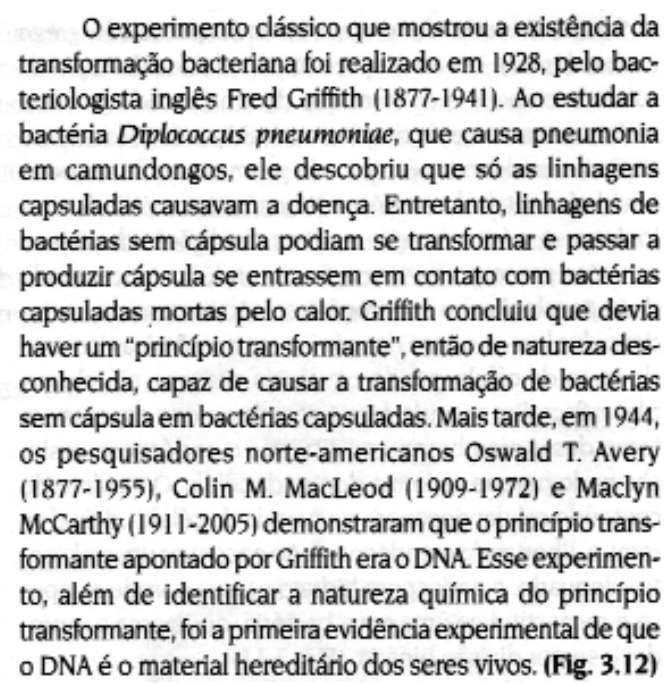

Figura 6 - Trecho retirado do Livro B, em que aparece uma explicação acerca dos experimentos de Griffith.

Constatamos que, mesmo com a tentativa de contextualização, as ideias originais não foram totalmente preservadas e ocorreu o uso inadequado de termos como: "ele descobriu..." e "demonstraram que o princípio transformante...". Não podemos dizer que Griffith “descobriu” ou que Avery et al. (1966) "demonstraram" algo por meio de experimentos, uma vez que, a partir dos resultados destes, somente é possível construir evidências favoráveis ou contrárias a uma determinada hipótese. A utilização de termos como "descobrir", "provar", "demonstrar" sugere que o problema foi resolvido definitivamente.

Como resultado de nossa investigação, apontamos dois aspectos:

- No contexto histórico os experimentos de Griffith sobre transformação contribuíram para o estabelecimento da relação entre a hereditariedade e o DNA. Porém, nos livros didáticos analisados há uma desarticulação entre os assuntos que envolvem a transformação bacteriana e estrutura e função do DNA. A abordagem do primeiro está inserida no conteúdo referente ao Reino Monera, enquanto que, as questões relativas ao DNA são apresentadas na temática sobre as substâncias orgânicas componentes dos seres vivos. 
- A transposição didática do conceito de transformação que encontramos nos livros analisados, de forma geral, preocupa-se principalmente em abordar aspectos atuais sobre o assunto.

Tendo em vista a riqueza de informações contidas no artigo original de Griffith, bem como a relevância de um tratamento histórico dos conteúdos, no entendimento do processo de construção do conhecimento, sugerimos o regaste do conceito de transformação originalmente presente nos trabalhos de Griffith e a partir dele integrarmos conteúdos de Genética e Microbiologia atuais. A nosso ver, essa é uma estratégia interessante, pois possibilita uma diminuição na distância existente entre o saber sábio e saber ensinado, bem como, uma integração de conteúdos que frequentemente aparecem fragmentados nos livros didáticos. Além disso, as distorções históricas e aquelas decorrentes da despersonificação, descontemporialização, descontextualização e naturalização são amenizadas.

\subsection{Proposta de abordagem dos experimentos de Griffith em sala de aula}

Os experimentos de Griffith podem ser explicados à luz da Genética e da Microbiologia, uma vez que o seu entendimento requer noções de hereditariedade e variabilidade, bem como de reprodução e técnicas de cultivo de bactérias. Desta forma, apresentamos esses experimentos como pano de fundo para uma proposta de Ensino que integra os conceitos dessas duas áreas.

Inicialmente, seria interessante apontarmos os motivos que desencadearam as investigações de Griffith acerca da transformação bacteriana a fim de fornecermos um panorama do contexto histórico e metodológico em que as pesquisas foram realizadas. Com isso, inevitavelmente surgirão questões sobre a existência das diferentes linhagens (R e S) de pneumococos, o que levaria às explicações referentes às variações. Faz-se necessária uma abordagem sobre as características morfológicas que diferenciam as colônias virulentas e avirulentas de pneumococos cultivadas nos experimentos de Griffith, denominadas de colônias S e R, respectivamente. Salientamos a importância de fazermos menção às técnicas adequadas ao crescimento de bactérias, que incluem o preparo de meio de cultura, tratamentos térmicos, manuseio de materiais laboratoriais, tais como, placas de petri, tubos de ensaio, entre outros.

Outra questão que pode ser explorada refere-se aos diferentes tipos de pneumococos da forma S, isto é, Tipo I, II e III. A caracterização desses tipos inclui diferenças na composição da cápsula de polissacarídeos presentes nos pneumococos. Cabe aqui uma discussão sobre as técnicas de análises sorológicas, uma vez que essas são utilizadas para identificação dos tipos. Por exemplo, se injetarmos em um coelho uma quantidade de sangue contendo pneumococos do Tipo I, o sistema de defesa (imunológico) desse animal, produzirá proteínas denominadas anticorpos que reagirão (aglutinarão) especificamente com o tipo inoculado. Cada tipo de pneumococo desencadeia a produção de um anticorpo específico correspondente. 
Afinal, quais seriam as causas dessas variações? Atualmente, podemos pautar essa discussão com base no conhecimento genético. Uma das maneiras de iniciá-la é por meio de explicações de conceitos como o de hereditariedade e variabilidade genética. A reprodução bacteriana por bipartição, isto é, uma célula originando duas novas, é responsável pelo aumento no número de células que formam as colônias de bactérias. Estas apresentam aspectos morfológicos característicos de cada linhagem que dependem do material genético presente em cada célula. Dessa forma, as células bacterianas originadas do processo de bipartição recebem cópias do material genético da célula da qual originaram. Durante esse processo, podem ocorrer alterações no material genético e essas podem ser herdáveis, ou seja, serem transmitidas, ao longo das gerações. Tais alterações são conhecidas por mutações, podem ser ao acaso ou induzidas, e correspondem a um dos fatores responsáveis pela variabilidade genética entre os organismos. Retomando os experimentos de Griffith, podemos considerar que a variante atenuada de pneumococos $\mathrm{R}$ é decorrente de mutação na linhagem de pneumococos S. Essa mutação seria responsável pela incapacidade das bactérias $\mathrm{R}$ em produzir a cápsula de polissacarídeos. Conforme Gardner e Snustad (1986), a forma S sofre mutação para a forma $\mathrm{R}$ a uma frequência de uma célula em 107, o que justifica a observação de variantes $\mathrm{R}$ após sucessivos cultivos de colônias da linhagem $\mathrm{S}$. Ressaltamos que a variante $\mathrm{R}$ derivada, por exemplo, de uma forma S Tipo I será diferente daquela derivada de uma forma S Tipo II. A existência de vários tipos de pneumococos distintos também pode ser explicada pela ocorrência de mutação.

Após essa explicação, uma pergunta extremamente pertinente seria: Qual a composição química do material genético? Seria uma proteína, um carboidrato ou um ácido nucleico? Como consideramos que os experimentos de Griffith contribuíram para o desenvolvimento dos estudos posteriores, que esclareceram as questões acima colocadas, nos reportamos novamente a eles. $\mathrm{O}$ mais conhecido experimento de transformação feito por Griffith refere-se àquele em que cultura de linhagem de pneumococos $\mathrm{S}$ do Tipo III mortas por aquecimento eram inoculadas em ratos juntamente com culturas de linhagem $\mathrm{R}$ atenuada (obtida a partir de culturas de linhagem S do Tipo II). Colônias de pneumococos S do Tipo III foram observadas em material coletado dos ratos mortos por pneumonia. Se neste caso, o ocorrido fosse devido à mutação da variante $\mathrm{R}$ do Tipo II para a $\mathrm{S}$ do Tipo III, as formas resultantes seriam $\mathrm{S}$ do Tipo II e não do Tipo III, como observado. Este processo ficou conhecido como transformação. Para Griffith o componente do extrato celular responsável pela transformação de um tipo em outro era uma proteína. Porém, convém lembrar que, na época em que os experimentos de Griffith sobre transformação bacteriana foram realizados não se sabia a natureza do material genético, que somente foi conhecida em trabalhos posteriores (AVERY et al., 1944). Segundo Gardner e Snustad (1986), 
Agora sabemos que o segmento de DNA no cromossomo dos pneumococos que carrega a informação genética que especifica a síntese da cápsula do Tipo III é fisicamente integrado no cromossomo da célula receptora da variante $\mathrm{R}$ do Tipo II por um processo específico de recombinação que ocorre durante a transformação (p.63).

Em linhas gerais, a transformação bacteriana envolve a incorporação de DNA exógeno ao material genético das células bacterianas, resultando em uma recombinação gênica herdável. Para que esse processo ocorra, as bactérias necessitam estar em condições fisiológicas adequadas à recepção do DNA exógeno. Esse estado é denominado de competência, que pode ser desencadeado de forma natural ou induzida. Esse último caso implica, por exemplo, em tratamentos térmicos e com cloreto de cálcio, que de maneira geral, alteram a permeabilidade da parede celular, o que possibilita a entrada de DNA exógeno através da membrana celular.

Diante do apresentado anteriormente, percebemos a viabilidade de relacionar aspectos genéticos e microbiológicos a partir dos experimentos de Griffith, o que possibilita a não fragmentação destes conteúdos e contribui para o entendimento da construção de conhecimento científico.

\section{CONSIDERACִ̃̃ES FINAIS}

Nossa análise sobre a transposição didática do conceito de transformação, realizada nos livros didáticos de Biologia, apontou a presença, nos livros didáticos, de elementos que caracterizam os processos despersonificação, descontemporialização, descontextualização e naturalização do saber sábio quando esse se torna um saber a ensinar e um saber ensinado, descritos por Chevallard. Por conta desses processos, o referido conceito é apresentado, na maioria dos livros observados como definitivo. É importante lembrarmos que muitos avanços científicos e tecnológicos ocorreram desde que Griffith propôs o conceito de transformação, e nesse sentido, embora a denominação transformação permaneça a mesma, ela denota (agrega) muitos conhecimentos contemporâneos. A incorporação de explicações recentes a fenômenos biológicos está perfeitamente adequada a uma transposição didática desejável. Porém, há que se estabelecer uma vigilância para que esses conhecimentos não sejam apresentados, tal como destacado por Astolfi e Develay (2001), como "verdades de natureza", em vez de estarem ligados a problematizações científicas. Percebemos também, em nossa análise, que há uma fragmentação dos conteúdos, sendo o conceito de transformação abordado em uma parte do livro diversa daquela em que a estrutura do DNA é estudada. Isso, a nosso ver, é problemático principalmente por dois motivos: primeiro porque reforça os processos de despersonificação, descontemporialização, descontextualização e naturalização do saber sábio, sugerindo, por exemplo, que poucos foram os 
estudos que contribuíram para que se chegasse à proposta de dupla hélice do DNA, e segundo, pois ao desvincularmos temas relacionados em sua origem, podemos dificultar o entendimento dos próprios conceitos.

A amplitude de conteúdos específicos, tanto da área da Genética como da Microbiologia, bem como, a ideia de Ciência não acabada, dinâmica e integrada que a proposta aqui apresentada sobre os experimentos de Griffith possibilita, a utilização desta no Ensino parece pertinente e interessante. Além do proposto no item anterior, uma diversidade de conteúdos pode ser explorada a partir da temática em questão, como por exemplo, a constituição e estrutura da molécula de DNA; os organismos geneticamente modificados; gráficos de curva de crescimento de bactérias, entre outros. Cabe ao professor selecionar os aspectos que achar mais adequado ao seu programa de ensino e tratá-los de forma integrada, conforme sugerido neste trabalho.

\section{NOTAS}

${ }^{1}$ Parte desse artigo foi apresentado no $11^{\circ}$ Seminário Nacional de História da Ciência e da Tecnologia, realizado em Niterói (RJ), em 2008.

${ }^{2}$ Algumas fontes mencionam 1877 e 1879 como possíveis datas para o nascimento de Griffith.

${ }^{3} \mathrm{O}$ trabalho de Griffith sobre transformação bacteriana foi originalmente publicado em 1928, no Journal of Hygiene (Cambridge). Em virtude da comemoração do vigésimo quinto aniversário de morte de Griffith, seu trabalho foi reimpresso em 1966. No presente artigo, como fonte primária, nós utilizamos a referida reimpressão.

${ }^{4}$ Inoculação é o ato de introduzir (injetar) algo em um organismo, como por exemplo, uma vacina ou uma determinada substância farmacêutica.

${ }^{5} \mathrm{O}$ termo virulência pode ser entendido como a capacidade de um microorganismo em causar doenças e/ou morte.

${ }^{6}$ Local apropriado para reprodução das bactérias.

${ }^{7}$ Efeito patogênico refere-se à patogenicidade de um agente biológico, ou seja, a capacidade de provocar uma determinada doença.

${ }^{8}$ Ressaltamos que Griffith realizou testes em que aquecia os pneumococos virulentos em diversas temperaturas para verificar qual era a mais adequada para causar a morte dos pneumococos e viabilizar a transformação.

${ }^{9}$ De maneira simplista, aglutinação é uma reação que ocorre devido a uma interação específica entre antígenos e anticorpos. 


\section{REFERÊNCIAS BIBLIOGRÁFICAS}

ARKWRIGHT, J. A., J. Variation in bacteria in relation to agglutination both by salts and by specific serum. J. Path. and Back, v. 24, p. 36-60, 1921.

ASTOLFI, J.; DEVELAY, M. A didática das ciências. Tradução de Magda Sento Sé Fonseca. 6 ed. Campinas: Papirus, 2001.

AVERY, O. T.; MACLEOD, M.; MACCARTY, M. Studies on the chemical nature of the substance inducing transformation of pneumococcal types. Induction of transformation by a desoxyribonucleic acid fraction isolated from pneumococcus Type III. The Journal of Experimental Medicine, v.79, p.137-158, 1944.

BRASIL. MEC. Programa Nacional do Livro para o Ensino Médio (PNLEM). Brasília, 2009.

CHEVALLARD, Y. La transpodición didáctica: del saber sabio al saber enseñado. Tradução de Claudia Gilman. Aique, 1991.

CHEVALLARD, Y.; JOHSUA, M. A. Un exemple d'analyse de la transposition didactique. La notion de distance. Recherches en Didactique des Mathématiques, v. 1, p. 159-239, 1982.

DAWSON, M. H. The Interconvertibility of $\mathrm{R}$ and $\mathrm{S}$ forms of pneumococcus. The Journal of Experimental Medicine, v. 47, n. 4, p. 577-591, 1928.

DAWSON, M. H., SIA, R. H. P. In vitro transformation of pneumococcal types. I. A technique for inducing transformation of pneumococcal types in vitro. The Journal of Experimental Medicine, v. 54, p. 681-699, 1931.

GARDNER, E. J.; SNUSTAD. D. P. Genética. 7.ed. Guanabara, Rio de Janeiro, 1986.

GRIFFITH, F. The significance of Pneumococcal Types. The Jounal of Higiene, v. 27, p. 113-159, 1928.

GRIFFITH, F. The significance of Pneumococcal Types. The Jounal of Higiene, v. 64, n. 2, p. 129165, 1966.

LEAL, M. C. Estudo piloto de transposição didática da cadeia alimentar, Revista Brasileira de Pesquisa em Educação em Ciências, v. 1, n. 2, p. 62-72, 2001.

VERRET, M. Le temps des études. Lille: Atelier de Réproduction de Théses, 1975.

Data de recebimento: 02/12/08

Data de aprovação: 24/08/09

Data de versão final: 10/09/09 
